\title{
MANAJEMEN PENGEMBANGAN MUSYAWARAH GURU MATA PELAJARAN (MGMP) SEBAGAI UPAYA MENINGKATKAN KOMPETENSI PROFESIONAL GURU PAI
}

\author{
Husna Amalia \\ Sekolah Tinggi Agama Islam Hasanuddin (STAIH) Pare \\ Email: amalia_husna25@yahoo.com
}

\begin{abstract}
Teacher professionalism is an important component that can determine success in the teaching and learning process in the classroom. In an effort to improve teacher professional competence there are several programs that can be done, one of them is by empowering Musyawarah Guru Mata Pelajaran (MGMP) for PAI teachers. MGMP is an opportunity for teachers to be able to develop themselves and innovate in developing the quality of learning in the classroom. This research is a literature review that aims to understand MGMP management as an effort to improve the professional competence of PAI teachers. The results of this study are MGMP requires planning, organizing, mobilizing and monitoring so that the objectives of the MGMP programs can contribute positively to the development of professional competencies for PAI teachers.
\end{abstract}

\section{Keywords: Management, MGMP, Professional Competence, PAI teacher}

\begin{abstract}
Abstrak
Profesionalisme guru merupakan salah satu aspek yang signifikan dalam menentukan keberhasilan pada kegiatan pembelajaran di kelas. Dalam upaya meningkatkan profesionalitas guru ada beberapa program yang dapat dilakukan salah satunya adalah dengan memberdayakan MGMP bagi guru PAI. MGMP merupakan sebuah peluang bagi guru untuk dapat mengembangkan diri dan berinovasi dalam mengembangkan kualitas pembelajaran di kelas. Penelitian ini merupakan sebuah kajian literatur yang bertujuan untuk memahami pengembangan manajemen MGMP dalam usaha meningkatkan profesionalitas guru PAI. Hasil dari kajian ini adalah MGMP memerlukan suatu manajemen yang mampu mengelola dengan adanya suatu perencanaan yang matang, pengorganisasian yang terstruktur, penggerakan, dan pengawasan sehingga tujuan dari program-program MGMP tersebut dapat memberikan kontribusi positif bagi pengembangan profesionalitas guru PAI.
\end{abstract}

Kata Kunci: Manajemen, MGMP, Kompetensi profesional, guru PAI 


\section{A. Pendahuluan}

Perkembangan ilmu pengetahuan dan teknologi pada era globalisasi yang pesat melahirkan tantangan pada berbagai aspek kehidupan manusia tak terkecuali pada kehidupan sosial beragama dan pendidikan. Kondisi ini menuntut guru harus mampu berperan aktif dalam menampilkan nilai-nilai pengajaran yang lebih bermakna dan penuh penghayatan. Guru yang profesional adalah berarti mampu berperan dalam mendidik, memberikan pengajaran, melakukan upaya pembimbingan, memberi pengarahan, memberi pelatihan dan penilaian, serta mengevaluasi peserta didik dengan menggunakan berbagai keahlian dan kecakapan hidup yang memenuhi standar mutu atau norma tertentu (Sumardi, 2016:1).

Tobroni dalam Husna (2016:207) mengungkapkan bahwa usaha dalam pemberdayaan guru penting untuk dilakukan. Terkait hal tersebut ada beberapa alasan yang penting untuk diungkapkan yakni: Pertama, peran guru adalah sebagai sumber edukasi yang utama walaupun saat ini kemajuan pembelajaran dan teknologi mengalami perkembangan pesat. Kedua, adanya tuntutan dan transparansi dalam penyelenggaraan pendidikan dan pembelajaran di sekolah pada era otonomi daerah dan penyelenggaraan pendidikan berbasis masyarakat (Community Based Education). Ketiga, adanya perubahan sosial yang diikuti dengan perubahan tuntutan masyarakat terhadap kompetensi lulusan pendidikan.

Guru profesional harus memiliki 4 kompetensi yaitu: 1) kompetensi kepribadian, 2) kompetensi sosial, 3) kompetensi pedagogik, dan 4) kompetensi profesional. Keempat kompetensi tersebut tidak dapat berdiri sendiri, tetapi saling berkaitan dan bersinergi satu sama lain. Di samping profesionalitas guru, kemajuan dalam bidang pendidikan ini tentu akan melibatkan semua komponen pendukungnya baik siswa, sekolah, maupun manajemen pengelolaan untuk meningkatkan kualitas guru secara optimal (Marlina, 2015:124).

Berbagai upaya telah dilakukan pemerintah dalam upaya peningkatan profesionalitas guru seperti adanya pendidikan lanjutan dalam jabatan, pembentukan forum-forum peningkatan kualitas guru seperti pembinaan Penilaian Kinerja Guru (PKG), Kelompok Kerja Guru (KKG), dan juga memberdayakan Musyawarah Guru Mata Pelajaran (MGMP). Hal ini sesuai dengan Kementrian 
Pendidikan Nasional yang menyebutkan dasar hukum pendirian MGMP. Berbagai program tersebut bertujuan untuk merencanakan, mengembangkan serta melakukan supervisi pembelajaran untuk meningkatkan kualitas pendidikan di sekolah (Alwi, 2009:104).

Suatu kenyataan yang dihadapi dunia pendidikan khususnya PAI di lembaga pendidikan formal saat ini adalah bahwa Guru PAI memiliki kompetensi dan kualifikasi yang heterogen sehingga berimplikasi pada kurang maksimalnya kinerja sehingga belum dapat tercapainya tujuan pendidikan secara holistik. Hal tersebut dapat dilihat dari kegiatan pembelajaran yang dilakukan oleh guru dan peserta didik di dalam kelas. Guru masih lemah dalam penguasaan aspek metodologi sehingga masih sering menggunakan metode dengan model konvensional yang memusatkan pembelajaran pada guru sehingga murid cenderung lebih pasif. Fasilitas media dan bahan ajar untuk mata pelajaran PAI juga masih sangat terbatas sehingga hal ini juga termasuk dalam beberapa aspek yang perlu dibenahi (Nugraha, 2014:57).

MGMP menurut Mulyasa merupakan suatu forum yang menjadi wadah bagi guru bidang studi sejenis dalam mengembangkan diri (Mulyasa, 2011:67). Dalam perkembangannya, MGMP masih belum sepenuhnya berjalan dengan optimal, dengan kata lain masih ditemukan beberapa kendala dalam permasalahan manajerial. Problematika tersebut sesungguhnya dapat diminimalisir apabila MGMP benar-benar melaksanakan kegiatan sesuai dengan standar pengembangan, pedoman pelaksanaan, beserta rambu-rambu pengembangan MGMP mulai dari standar pengorganisasian, program kerja dan kegiatan, SDM, pengelolaan, pembiayaan, serta pemantauan, dan evaluasi. Oleh sebab itu, maka dalam artikel ini penting kiranya untuk mengkaji tentang manajemen pengembangan MGMP beserta kontribusinya dalam meningkatkan kompetensi profesional guru PAI.

\section{B. Landasan Teori}

\section{Konsep Dasar Manajemen}

Secara konsep bahasa manajemen merupakan istilah yang berasal dari bahasa inggris manage yang berarti melaksanakan, dan mengelola. Sedangkan 
orang yang mengatur suatu pekerjaan atau kerja sama yang baik dengan menggunakan SDM sebagai sarana mencapai tujuan manajerial disebut manajer. Manajemen menurut istilah mempunyai banyak pengertian. Para pakar mengemukakan beberapa pengertian tentang manajemen di antaranya adalah suatu kegiatan dalam rangka pencapaian tujuan yang sebelumnya telah ditentukan terlebih dahulu dengan memberdayakan orang lain (Saefullah, 2016:4).

Menurut Sugiyono, manajemen dan administrasi mempunyai persamaan (sinonim), sehingga arti manajemen sama dengan administrasi. Dalam hal ini administrasi maupun manajemen diartikan sebagai proses pengelolaan SDM dalam rangka pecapaian tujuan seefektif dan seefisien mungkin. Proses pengelolaan ke dalam fungsi manajemen yang terdiri atas merencanakan, mengorganisaskan, menggerakkan, dan mengontrol. Sumber daya yang dikelola terdiri atas manusia, uang, materi, metode, mesin, dan pasar. Sedangkan kriteria tujuannya adalah efektif dan efisien (Lubis, 2014:153).

Dari pemaparan beberapa pengertian tentang manajemen yang dikemukakan para ahli pada definisi di atas, menyimpulkan bahwa manajemen merupakan kegiatan seseorang dalam mengelola suatu organisasi, lembaga, sekolah, maupun perusahaan melalui proses merencanakan, mengorganisasikan, menggerakkan dan mengawasi yang dilaksanakan untuk mencapai suatu tujuan yang efektif dan efisien.

\section{Fungsi Manajemen}

Dalam melandasi sekaligus mempertajam kegiatan analisis MGMP, teori yang digunakan sebagai landasan analisis adalah Teori Fungsi Manajemen George R. Terry (POAC) yang artinya Planning, Organizing, Actuating, Controlling (Arikunto and Yuliana, 2008:7). Fungsi pokok manajemen yang dikemukakan Goorge R. Terry baik dalam Planning, Organizing, Actuating, dan Controlling pada penyelenggaraan MGMP tidak terlepas dari peran guru di dalamnya. Bahkan guru adalah tokoh utama yang menentukan proses manajemen di atas. Berikut ini peneliti paparkan fungsi- fungsi dari manajemen.

\section{Perencanaan (Planning)}

Perencanaan adalah pemilihan realita-realita dan upaya menghubungkan antara realita yang satu dengan realita yang lainnya, 
kemudian membuat peramalan tentang suatu keadaan dan merumuskan tindakan untuk masa mendatang yang mungkin diperlukan dalam mencapai tujuan (R.Terry, 2011:7). Oleh karenanya perencanaan merupakan suatu proses tindakan yang berhubungan dengan upaya merumuskan agenda yang memuat penentuan suatu kebijakan berupa prosedur atau metode yang akan dilaksanakan dalam upaya mencapai tujuan.

2. Pengorganisasian (Organizing)

Organisasi merupakan serangkaian kesatuan yang saling berkoordinasi dengan batasan-batasan tertentu serta mampu bekerja sama untuk mencapai kerja tim atau kelompok (Edison, 2016: 49). Pengorganisasian yang baik memperhatikan batas-batas yang jelas terkait dengan keberadaan individu di luar maupun di dalamnya. Organisasi memberikan konsep yang terstruktur terkait dengan aktivitas maupun kegiatan anggota.

3. Penggerakan (Actuating)

George R. Terry mendefinisikan actuating adalah usaha untuk menggerakkan anggota-anggota dalam tim sehingga mereka berupaya dalam prncapaian sasaran-sasaran organisasi/lembaga (2011:313). Peneliti berpandangan bahwa actuating adalah kegiatan yang menggerakkan dan mengusahakan agar para individu melakukan tugas dan kewajibannya. Mereka melakukan rencana pada kegiatan yang nyata serta dibina untuk mencapai tujuan sesuai dengan keahliannya. Di samping itu fakor-faktor yang diperlukan dalam pergerakan juga ikut memberikan pengaruh yakni adanya kepemimpinan, sikap dan moril, tata hubungan, perangsang, supervisi, dan disiplin.

4. Pengawasan (Controlling)

George R. Terry mendefinisikan pengawasan adalah menentukan suatu pelaksanaan kegiatan dengan evaluasi kinerja serta mengontrolnya sehingga hasil akan sesuai dengan perencanaan awal yang telah disusun (2011:395). Dari definisi tersebut dapat di simpulkan bahwa controlling sebagai fungsi manajemen adalah aktifitas untuk meneliti dan mengetahui hasil sampai dimana pelaksanaan yang telah dilakukan dalam proses keseluruhan organisasi, sudahkah mencapai tujuan yang direncanakan atau belum. Setiap 
kegiatan yang dilakukan unsur pimpinan ataupun anggota tentu memerlukan evaluasi. Dengan mengetahui kekurangan maupun kesalahan maka perbaikan selanjutnya dapat dilakukan dengan mudah.

\section{Musyawah MGMP}

Urgensi musyawarah dalam organisasi telah banyak diakui manfaatnya. Hal ini juga ditegaskan dalam salah satu surat dalam al-Qur'an yaitu surat asy-Syuura. Dalam QS. Asy-Syuura ayat 38 menunjukkan pentingnya suatu musyawarah sebagai berikut.

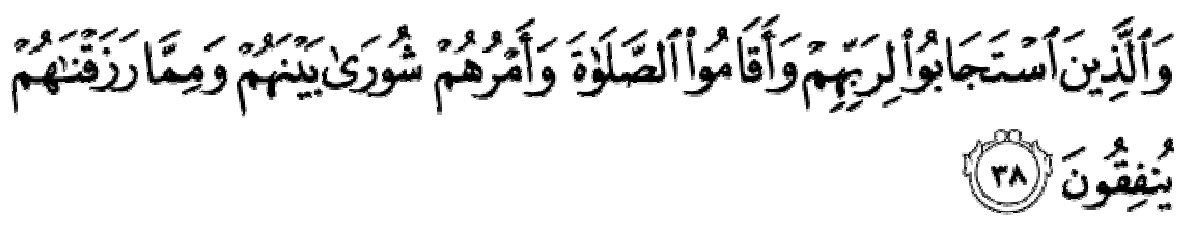

Merujuk pula pada teori yang disampaikan oleh Norman Triplett bahwa rangsangan dari orang lain dapat menimbulkan keinginan untuk berkompetisi dalam melaksanakan tugas-tugas motori sehingga hal tersebut dapat memberikan fasilitas pada kinerja individu menjadi lebih baik. Serta teori dari Zajonc yang dikenal dengan drive theory yang menyebutkan bahwa kehadiran orang lain menyebabkan individu berada pada kondisi siaga sehingga terjadi rangsangan atau peningkatan motivasi (Husna, 2016:215). Dari teori ini dapat disimpulkan bahwa bekerja secara kelompok dapat meningkatkan performa atau kinerja dari individuindividu. MGMP adalah suatu perkumpulan profesional dari guru-guru mata pelajaran yang homogen yang berada pada tiap-tiap sekolah. Guru yang dimaksud berada pada jenjang SMP/MTs dan SMA/MA negeri atau swasta yang bertugas mengelola mata pelajaran dengan menyesuaikan pada kurikulum yang ada. Guru bertugas menerapkan pembelajaran sesuai dengan kurikulum di kelas kelas. Oleh sebab itu adanya sinergi yang kuat diantara para guru sangat diperlukan (Sa'ud, 2009:107). MGMP bertujuan dalam upaya meningkatkan profesionalisme guru dalam melaksanakan pembelajaran yang bermutu sesuai kebutuhan peserta didik sehingga dalam forum ini MGMP merupakan wadah yang sesuai untuk melakukan supervisi kolegial yakni lebih diarahkan pada upaya untuk membenahi dan mengembangkan kemampuan guru dalam pengelolaan KBM. 


\section{Manajemen MGMP}

Standar pengembangan MGMP adalah kriteria-kriteria yang wajib dimiliki oleh MGMP yang meliputi organisasi, program, pengelolaan sarana dan prasarana, sumber daya manusia, pembiayaan, dan penjaminan mutu. Unsur-unsur tersebut bisa dikatakan sebagai manajemen MGMP (Pendidik, 2008:7). Manajemen MGMP diartikan sebagai kegiatan mengatur, mengurus dan mengelola. Lingkup MGMP meliputi: 1) Organisasi, yaitu struktur kepengurusan, landasan dan acuan kerja, serta kerangka teknis organisasi. 2) Program, yaitu halhal yang berkaitan dengan merencanakan, melaksanakan dan mengevaluasi kegiatan, tujuan dan sasaran yang akan dicapai. 3) Pengelolaan, yaitu hal-hal yang berhubungan dengan proses pelaksanaan organisasi yang bersifat teknis, pelaksanaan acuan kerja dan sebagainya. 4) Sarana dan prasarana, adalah fasilitas dalam bentuk fisik untuk menunjang berhasilnya pelaksaaan MGMP. 5) Pembiayaan, yaitu dana yang digunakan untuk kegiatan MGMP, mulai dari perencanaan, sirkulasi, pelaporan dan evaluasi. 6) Penjaminan Mutu merupakan suatu sistem untuk mengatur kesesuaian antara pelaksanaan MGMP dengan prosedur-prosedur yang ditetapkan.

\section{Kompetensi Profesional Guru PAI}

Profesionalisme guru tergantung dari adanya kompetensi yang harus dimiliki guru tersebut yang di antaranya mencakup empat aspek sebagai berikut (Mulyasa, 2008:75): 1) Kompetensi Pedagogik. 2) Kompetensi Kepribadian. 3) Kompetensi Profesioanal. 4) Kompetensi Sosial. Kompetensi pedagogik merupakan kemampuan kinerja guru dalam mengelola kegiatan pembelajaran yang dilakukan dengan peserta didik yang meliputi kegiatan memberikan keilmuan dan pemahaman kepada peserta didik, merancang dan melaksanaan pembelajaran seperti yang telah tertulis dalam RPP, mengevaluasi hasil belajar, dan mengembangkan peserta didik untuk mewujudkan berbagai potensi yang dimilikinya. Kompetensi kepribadian merupakan kemampuan yang terwujud dalam kepribadian guru tersebut meliputi sikap yang stabil, dewasa, arif, bijaksana dan berwibawa sehingga mampu menjadi teladan bagi peserta didik dengan mencerminkan akhlak yang mulia. 
Kompetensi profesional merupakan kemampuan dalam menguasai materi pembelajaran secara luas dan mendalam sehingga dapat membimbing peserta didik untuk mencapai standar kompetensi yang ditetapkan dalam standar nasional pendidikan. Kompetensi sosial merupakan kemampuan guru sebagai anggota dari masyarakat untuk aktif dalam berkomunikasi dan bersosialisasi dengan baik kepada peserta didik, sesama pendidik, tenaga kependidikan, orang tua/wali peserta didik, dan masyarakat sekitar.

Guru yang mengikuti MGMP akan melakukan diskusi atau bertukar pengalaman dalam mengembangkan kompetensi guru, salah satunya adalah yang terkait dengan kompetensi professional. Dalam forum tersebut guru saling memberikan masukan tentang proses membuat perangkat pembelajaran yang benar, pembuatan soal, pengembangan media berbasis teknologi, inovasi-inovasi terkait model pembelajaran, problematika dalam pembelajaran beserta solusinya, dan program pengembangan diri lainnya yang bermanfaat. Dengan demikian, kehadiran MGMP menjadi suatu forum berkumpulnya para guru untuk mengembangkan profesionalitasnya diharapkan mampu menyatukan visi dan misi dalam menentukan sikap dan tindakan terhadap berbagai problematika yang muncul dalam proses belajar mengajar di sekolah sehingga dapat diambil solusi yang tepat, efektif dan efisien.

\section{Metode Penelitian}

Jenis penelitian ini merupakan penelitian kajian literatur, yang datanya bersumber dari buku, jurnal, hasil penelitian, serta data dari website. Hal-hal yang menjadi persoalan adalah bahwa belum maksimalnya kinerja guru secara profesional sehingga membutuhkan suatu organisasi yakni MGMP PAI yang menaungi pengembangan kompetensi guru. Data yang diperoleh dari sumbersumber tersebut dikumpulkan dan dianalisis dengan menggunakan analisis deskriptif yang diiringi dengan pengamatan lapangan. Pengumpulan data bersumber dari website, buku, dan hasil penelitian yang disesuaikan berdasarkan kebutuhan penelitian. 
D. Hasil

\section{Manajemen Pengembangan MGMP PAI}

1. Tahap Perencanaan

MGMP PAI tentu memiliki perencanaan dalam melaksanakan organisasinya. Di dalam AD/ART MGMP sekurang-kurangnya berisi tentang: nama, visi dan misi organisasi, tempat pelaksanaan, kepengurusan, keanggotaan, program, tata tertib organisasi, dll. Visi dan misi dari MGMP berkaitan erat dengan upaya peningkatan kompetensi profesional guru PAI. Penyusunan program dimaksudkan untuk mencapai tujuan organisasi sehingga harus berupaya seefektif mungkin dalam memilih dan memilah program-program yang bermanfaat bagi pengembangan kompetensi guru.

Guru dalam mengikuti MGMP membuat perencanaan kegiatan dengan cara memberikan motivasi dalam meningkatkan kemampuan dan keterampilan serta membuat evaluasi program kegiatan pembelajaran, membantu guru dalam memperoleh informasi dari berbagai sumber, melalui pertemuan rutin dan pelatihan, membantu memecahkan masalah yang berhubungan dengan kegiatan pembelajaran, menjalin hubungan kerja sama antar guru

Program MGMP PAI tersebut disusun dan dikembangkan dengan memperhatikan berbagai problematika dalam pembelajaran PAI, adanya kebijakan pendidikan, dan kondisi wilayah. Program yang dikembangkan sekurang-kurangnya meliputi: (a) Peningkatan kompetensi guru PAI yaitu kompetensi profesional, pedagogis, kepribadian, sosial dan kepemimpinan.

(b) Pembinaan karir dan prestasi kerja guru PAI yang berkaitan dengan unsur pengembangan diri maupun pengembangan profesi dengan melaksanakan kegiatan karya tulis/karya ilmiah, menemukan teknologi yang tepat dalam bidang pendidikan. 3) Membuat alat peraga yang dapat menunjang proses pembelajaran 4) Mengikuti kegiatan pengembangan kurikulum dan selalu mengikuti kajian terbaru yang berkaitan dengan pendidikan.

2. Tahap Pengorganisasian 
Pada tahap pengorganisasian, dalam MGMP memiliki struktur organisasi yang dapat membantu terlaksananya program kegiatan. Dalam struktur organisasi tersebut terdiri dari ketua, wakil, bendahara, sekertaris, dan sie bidang. Keberadaan struktur anggota ini memiliki tugas dan kewajiban masing-masing. Materi musyawarah yang disampaikan dalam agenda MGMP disesuaikan dengan permasalahan yang muncul selama pelaksanaan pembelajaran di kelas, kemudian didiskusikan bersama guru lain dipandu oleh ketua Musyawarah.

Pada setiap kegiatan peserta musyawarah diberikan tanggung jawab sesuai dengan materi yang akan dikaji pada setiap pertemuan. Misalnya pada materi penyusunan Silabus dan RPP, peserta musyawarah dibagi menjadi beberapa kelompok yang disesuaikan dengan kelas yang diajarnya kemudian mendiskusikan hasil dari pembuatan Silabus dan RPP tersebut untuk mendapatkan kemufakatan. Kegiatan MGMP ini diadakan secara berkala setiap dua bulan sekali dengan materi dan nara sumber yang telah ditentukan.

3. Tahap Penggerakan

Dalam tahap penggerakan maka guru PAI dapat melaksanakan hasil dari kegiatan MGMP dalam kegiatan pembelajaran sesuai dengan tugas pokok dan fungsi guru, menerapkan silabus dan RPP dalam pembelajaran di kelas sesuai dengan standar yang berlaku, menerapkan metode mengajar serta penguasaan materi pelajaran yang sesuai, mengadakan komunikasi langsung kepada siswa sehingga siswa dapat terlibat secara aktif dalam pembelajaran di dalam maupun di luar kelas. Pembelajaran PAI akan mendapatkan manfaatnya apabila dilaksanakan dengan pembelajaran yang menarik, dapat menjadi penggerak dalam kegiatan keagamaan di sekolah.

Di samping sebagai pengajar, guru juga berperan sebagai pembimbing. Peran guru PAI di dalam membimbing siswa terlihat pada saat guru berusaha menjadi pendengar dan memberikan arahan ketika ada siswa yang mengalami masalah belajar atau pengembangan diri. Guru PAI juga berupaya melakukan binaan dalam proses belajar mengajar baik secara akademis maupun non akademis. Di samping itu guru PAI juga 
mendiskusikan penerapan dari hasil MGMP kepada guru mata pelajaran lain serta kepala sekolah.

4. Tahap Pengawasan

Peran guru PAI dalam MGMP tidak hanya sebagai peserta melainkan juga sebagai pengawas kegiatan. Selama kegiatan para peserta ikut bertanggung jawab terhadap kesuksesan kegiatan MGMP. Semua peserta ikut serta dalam menjaga ketertiban, keamanan dan kelancaran MGMP. Sehingga dalam kegiatan ini semua peserta melakukan pengawasan baik langsung maupun tidak langsung.

\section{Kontribusi MGMP sebagai Upaya Peningkatan Kompetensi Profesional Guru PAI}

1. MGMP sebagai Sarana Diskusi Guru

Dalam proses pembelajaran antara satu guru dengan yang lainnya tentu mengalami problem yang berbeda baik dalam hal metode pembelajaran maupun penggunaan media pembelajaran. Kegiatan diskusi antar guru bertujuan agar guru memperoleh ide yang kreatif dalam penerapan pembelajaran. Guru akan saling memberikan masukan dan tanggapan tentang berbagai metode mengajar yang telah diterapkan dari masing-masing sekolah, sehingga dari berbagai pengalaman tersebut akan menjadi bahan pertimbangan guru lainnya untuk memilih metode atau media pembelajaran yang sesuai dengan karakter sekolah, guru, maupun siswa.

2. MGMP sebagai Sarana Penguatan Materi Pembelajaran

Dalam kegiatan MGMP maka guru PAI perlu menyamakan visi misi terkait dengan pembelajaran. Tentu saja hal tersebut tidak terlepas dari materi yang akan diajarkan kepada siswa. Penting bagi guru untuk menganalisis lebih dalam terkait bahan ajar yang digunakan, menyelaraskan materi yang diajarkan dengan menggunakan berbagai sumber bacaan yang relevan, dan menyusun perangkat pembelajaran yang sesuai. Materi yang diajarkan kepada siswa harus sesuai dengan standar yang berlaku, sehingga tidak terjadi adanya kekurangan materi maupun materi yang berlebihan sehingga dapat menyebabkan tidak tercapainya tujuan dalam pembelajaran. 
3. MGMP sebagai Sarana Penguatan Keterampilan Guru

MGMP juga merupakan sarana bagi guru untuk mengembangkan kemampuannya terutama dalam hal teknologi. Tantangan guru saat ini tentu selalu berkaitan dengan teknologi dan hal-hal yang modern, untuk itu maka guru dituntut untuk selalu memperluas wawasan dan pengalamannya. Pengembangan keterampilan dalam bidang teknologi ini akan membantu guru dalam membuat media pembelajaran berbasis teknologi yang menarik sehingga dapat menunjang keberhasilan dalam pembelajaran. Dalam MGMP juga terdapat adanya agenda untuk workshop maupun seminar untuk membantu para guru PAI dalam mengembangkan keterampilan mengajarnya.

\section{E. Pembahasan}

\section{Implementasi dalam Manajemen MGMP PAI}

Program-program dalam MGMP PAI menekankan kepada peningkatan kompetensi guru seperti menyusun perangkat pembelajaran, menyusun soal ulangan tengah semester dan akhir semester, penyusunan modul, pengembangan media pembelajaran, metode penyampaian di kelas, dll. Perencanaan sangat diperlukan dalam setiap kegiatan. Dengan demikian, maka semua kegiatan perlu menyusun perencanaan termasuk di dalamnya adalah aktivitas pendidikan dan pelatihan serta workshop dan kegiatan pengembangan lain yang diperlukan oleh guru. Perencanaan yang baik akan membuat kegiatan bisa berlangsung teratur dan terukur. Pada perencanaan ini maka perlu dilakukan sosialisasi secara berulang dalam setiap musyawarah sehingga terdapat manfaat yang signifikan terhadap peningkatan kompetensi guru seperti yang tertuang di dalam AD/ART MGMP.

Guru PAI yang mengikuti MGMP mendapatkan surat tugas dari kepala sekolah. Surat tugas yang diberikan kepada guru bersangkutan dibuktikan dengan bukti kehadiran dari ketua musyawarah MGMP. Kepala sekolah dalam kajian ini berperan untuk memberikan umpan balik kepada guru PAI yang telah mengikuti MGMP untuk dapat menyampaikan dan menerapkan ide atau gagasan yang telah didapat dari kegiatan tersebut. Guru PAI sebagai peserta MGMP mempunyai kesempatan dalam memberikan kontribusi berupa pemikiran sehingga hasil terbaik akan menjadi keputusan musyawarah. Peserta musyawarah saling bertukar 
pengalaman tentang pembelajaran PAI kepada siswa. Kemudian dari masalah pembelajaran dapat dicari solusinya secara musyawarah contohnya dalam masalah keluasan materi pelajaran PAI, masalah komunikasi dalam pembelajaran, dll.

Dalam penyusunan Silabus dan RPP, peserta musyawarah dibagi menjadi beberapa kelompok kemudian mereka berdiskusi untuk mendapatkan kemufakatan dalam kesamaan Silabus dan RPP. Sekretaris musyawarah bertugas membuat undangan, mencatat kehadiran dan menyimpan dokumen MGMP. Musyawarah ini diadakan secara berkala setiap dua bulan sekali dengan materi dan nara sumber yang ditentukan dan disesuaikan dengan kebutuhan pengembangan kompetensi guru PAI.

Sejalan dengan yang di ungkapkan oleh Amirudin dalam penelitiannya (2017:123) pada ruang lingkup tehnologi pendidikan mengenai fungsi pengelolaan organisasi, bahwa fungsi dari pengelolaan organisasi memerlukan fungsi pengembangan dengan sumber belajar yang terdiri dari guru, materi, metode, media dan lingkungan yang kondusif bagi siswa. Sehingga dalam pengorganisasian pada MGMP PAI perlu adanya penjabaran tugas dari masingmasing personil pengurus. Adanya pengelolaan personil akan mempermudah kinerja dari anggota tersebut dalam melaksanakan setiap rencana yang telah disusun.

Mengikuti MGMP memiliki peranan penting untuk lebih memahami pembelajaran PAI. Guru PAI dalam pelaksanaan pembelajaran di kelas dituntut untuk aktif dalam melaksanakan hasil musyawarah. Misalnya dalam menerapkan silabus dan RPP dalam pembelajaran di kelas guru memberikan pelajaran dengan menerapkan metode mengajar serta penguasaan materi pelajaran yang sesuai dengan RPP. Pembelajaran menjadi menarik perhatian siswa tidak hanya dengan menggunakan metode ceramah yang monoton tetapi juga dapat dilakukan dengan bermain peran maupun diskusi. Pembelajaran PAI juga dapat dilaksanakan dengan menggunakan pendekatan saintifik, tidak hanya praktek yang terbatas di kelas, tapi juga dapat dilaksanakn di luar kelas.

Peningkatan kompetensi kepribadian guru PAI dalam MGMP dibuktikan dengan kemampuan berinteraksi dengan sesama guru maupun siswa. Kompetensi sosial ditunjukkan pada saat guru PAI membimbing siswa. Kompetensi 
profesional ditunjukkan guru PAI dalam aspek kedisiplinan mengajar dan mengikuti kegiatan MGMP. Kompetensi kepemimpinan ditunjukkan guru PAI dengan mengikuti dan menggerakkan kegiatan keagamaan di Madrasah. Pada rangkaian kegiatan MGMP semua peserta memelihara ketertiban, keamanan dan kelancaran berlangsungnya MGMP. Selanjutnya, pengawasan MGMP dilakukan mulai dari awal sampai dengan berakhirnya kegiatan Dengan demikian, semua peserta melakukan pengawasan baik langsung maupun tidak langsung dalam kegiatan MGMP ini.

\section{Implikasi MGMP bagi Guru PAI}

MGMP memberikan peluang bagi guru untuk berdiskusi dalam mengembangkan pembelajaran menjadi lebih bermutu baik dari segi materi, media, konsep, dan penyampaian dalam mengajar. Setiap guru tentu memiliki pengalaman yang berbeda-beda dalam mengajar sehingga berbekal dari pengalaman tersebut guru dapat saling mengarahkan guru yang lain tentang konsep pembelajaran yang lebih menarik. Kegiatan MGMP ini bertujuan untuk meningkatkan kemampuan guru PAI supaya terus berinovasi dalam mencapai hasil pembelajaran yang lebih optimal.

Guru PAI wajib untuk selalu memperluas wawasan dengan selalu memperkaya bacaan-bacaan dan informasi lain yang didapat melalui internet maupun media cetak. Penguasaan materi PAI juga dapat dilakukan dengan aktif mengikuti workshop maupun seminar yang berkaitan dengan pengembangan kompetensi guru PAI. Sikap kritis juga harus dimiliki oleh guru PAI terkait adanya teks-teks yang terdapat pada buku ajar PAI yang disampaikan kepada siswa. Sikap kritis tersebut dapat ditunjukkan dengan cara menganalisis materi yang ada kemudian melakukan evaluasi.

Guru PAI juga harus mahir dalam penguasaan teknologi karena siswa yang mereka hadapi sekarang hampir setiap saat bersentuhan dengan media elektronik maupun internet yang memiliki koneksi serba cepat. Sehingga tidak menutup kemungkinan jika siswa akan mudah merasa bosan jika guru hanya mengajarkan materi PAI dengan cara konvensional tanpa memperhatikan perkembangan 
teknologi yang ada. Kemampuan berkomunikasi dan mengembangkan media yang menarik akan selalu menjadi topik khusus yang perlu dikaji pada forum MGMP.

\section{F. Kesimpulan}

Manajemen pengembangan MGMP memiliki beberapa prinsip dasar dalam menjalankan program-programnya di antaranya adalah perencanaan yang berkaitan dengan perumusan program yang tepat sehingga tujuan dari program MGMP dapat tercapai. Pengorganisasian merupakan penentuan struktur keanggotaan dari orang-orang yang terlibat dalam MGMP sehingga jelas dengan tugas atau kewajiban masing-masing untuk memajukan program MGMP. Pergerakan merupakan tahapan adanya aktifitas konkret yang telah diwujudkan terkait dengan program-program MGMP yang telah direncanakan. Selanjutnya adalah pengawasan yakni tahapan di mana suatu program memerlukan suatu kontrol dan evaluasi untuk membuat program tersebut berjalan lebih baik lagi. Adanya MGMP memiliki kontribusi penting bagi peningkatan kompetensi profesional guru PAI yakni sebagai sarana berdiskusi guru, sebagai sarana penguatan materi pembelajaran, dan sebagai sarana penguatan keterampilan guru

\section{Daftar Pustaka}

Alwi, M. 2009. Peran Kelompok Kerja Guru (KKG) dalam Meningkatkan Profesional Guru Sains Sekolah Dasar Kecamatan Suralaga, Educatio, 4(2), pp. 101-117.

Amirudin, M. 2017. Manajemen Musyawarah Guru Mata Pelajaran (MGMP) dalam Peningkatan Kompetensi Guru Akidah Akhlak MTsN Klaten di Gergunung Klaten Utara Kabupaten Klaten Tahun 2017. IAIN Surakarta.

Arikunto, S. and Yuliana, L. 2008. Manajemen Pendidikan. Yogyakarta: Aditya Media.

Edison, E. 2016. Manajemen Sumber Daya Manusia. Bandung: Alfabeta.

Husna, F. 2016. Peran Musyawarah Guru Mata Pelajaran (MGMP) untuk Meningkatkan Kompetensi Profesional Guru PAI, Didaktika Religia, 4(2), pp. 207-215.

Lubis, R. 2014. Efektivitas dan Efisiensi Pelaksanaan Manajemen Berbasis Kompetensi dalam Mencapai Tujuan Sekolah, Forum Paedagogik, 6(2), pp. 151-168.

Marlina, L. 2015. Manajemen Sumber Daya Manusia (SDM) dalam Pendidikan, Istinbath, 15(17), pp. 123-139.

Mulyasa. 2008. Standar Kompetensi dan Sertifikasi Guru. Bandung: Remaja 
Rosdakarya.

Mulyasa. 2011. Manajemen \& Kepemimpinan Kepala Sekolah. Jakarta: Bumi Aksara.

Nugraha, S. 2014. Pembelajaran PAI Berbasis Media Digital. Ta'lim, 12(1), pp. $55-67$.

Pendidik, D. P. 2008. Panduan KKG dan MGMP. Jakarta: Departemen Pendidikan Nasional.

R.Terry, G. 2011. Asas-Asas Manajemen. Bandung: PT Alumni.

Sa'ud, U. S. 2009. Pengembangan Profesi Guru. Bandung: Alfabeta.

Saefullah. 2016. Manajemen Pendidikan Islam. Bandung: Pustaka Setia.

Sumardi. 2016. Pengembangan Profesionalisme Guru Berbasis MGMP: Model dan Implementasinya untuk Meningkatkan Kinerja Guru. Yogyakarta: Deepublish. 